\title{
BMAL1 dephosphorylation determines the pace of the circadian clock
}

\author{
Ueli Schibler \\ Department of Molecular Biology, Sciences III, University of Geneva, 1211 Geneva, Switzerland
}

In mammals, virtually all body cells harbor cell-autonomous and self-sustained circadian oscillators that rely on delayed negative feedback loops in gene expression. Transcriptional activation and repression play a major role in keeping these clocks ticking, but numerous post-translational mechanisms-and particularly the phosphorylation of core clock components by protein kinases-are also critically involved in setting the pace of these timekeepers. In this issue of Genes \& Development, Klemz and colleagues (pp. 1161-1174) now show how dephosphorylation of BMAL1 by protein phosphatase 4 (PPP4) participates in the modulation of circadian timing.

Most light-sensitive organisms from bacteria to mammals harbor circadian clocks that help them coordinate daily recurring processes in a proactive manner. In mammals, a master pacemaker in the brain's suprachiasmatic nucleus (SCN) orchestrates the phases and activities of subsidiary clocks in nearly all body cells. The molecular makeup of circadian oscillators relies on two negative transcriptional-translational feedback loops (TTFLs) (Dibner et al. 2010). In the primary TTFL, BMAL1 and CLOCK stimulate the transcription of genes encoding their own repressors (PER1, PER2, CRY1, and CRY2). The secondary TTFL, which drives the cyclic transcription of Bmal1 and Clock, is composed of members of the orphan nuclear receptor families REV-ERB (REV-ERB $\alpha, \beta)$ and ROR (ROR $\alpha$, $\beta, \gamma)$. The cyclic expression of REV-ERBs is governed by the primary TTFL, and the two TTFLs are thus tightly coupled.

The term TTFL is actually misleading, as it implies that rhythmically controlled translation participates in running the clock. However, transcriptome-wide ribosome profiling experiments in mouse livers (Janich et al. 2015) and cultured human U2OS cells (Jang et al. 2015) revealed nearly constant translation efficacies (i.e., ribosome footprints/mRNA) throughout the day for mRNAs encoding core clock components. In contrast, post-translational mechanisms play essential roles in determining critical

[Keywords: BMAL1; CLOCK; circadian clock; circadian rhythm; phosphorylation; protein phosphatase 4] Correspondence: ueli.schibler@unige.ch

Article is online at http://www.genesdev.org/cgi/doi/10.1101/gad.348801. 121 . parameters of circadian oscillators, such as period length, phase, and amplitude. The cyanobacteria clock represents the most spectacular case for post-translational regulation. It works perfectly well in the absence of transcription and translation, and an oscillator generating temperature-compensated 24-h phosphorylation-dephosphorylation cycles can be reconstituted in the test tube with just three proteins (KaiA, KaiB, and KaiC) and ATP (Nakajima et al. 2005). Among the post-translational modifications of metazoan core clock proteins, the phosphorylations of serine $(S)$ and threonine $(T)$ residues by several kinases have been studied intensively. In fact, all positive and negative limb members of the molecular clock are heavily phosphorylated, and some of the S/T phosphorylations are essential to generate delays between rhythmic transcription and protein accumulation, thereby ensuring that the oscillations do not collapse into equilibrium. Moreover, S/T phosphorylations within core clock proteins can strongly affect the period length-and thereby the phase-of the oscillator (Reischl and Kramer 2011). For example, a single point mutation (S662G) in PER2 causes familial advanced sleep phase syndrome (FASPS) in humans by attenuating the cooperative phosphorylation at nearby $S$ residues by casein kinase $1 \delta$ (Toh et al. 2001).

Obviously, the phosphorylation status of proteins depends on the activities of both protein kinases and protein phosphatases. While there is a rich literature on the former, very little is known about the latter. In their very elegant study in this issue of Genes \& Development, Klemz et al. (2021) identified protein phosphatase 4 (PPP4) as an important player in circadian timing. They performed an RNA interference (RNAi)-based loss-of-function screen in human U2OS cells, targeting all known catalytic subunits of phosphoprotein phosphatases (PPPs) expressed in these cells. Bioluminescence cycles, generated by the circadian expression of a Bmall-luciferase reporter gene, served as a readout in this screen. The depletion and overexpression of PPP4C resulted in a marked shortening and lengthening, respectively, of the period length. In a clever

(C) 2021 Schibler This article is distributed exclusively by Cold Spring Harbor Laboratory Press for the first six months after the full-issue publication date (see http://genesdev.cshlp.org/site/misc/terms.xhtml). After six months, it is available under a Creative Commons License (Attribution-NonCommercial 4.0 International), as described at http://creativecommons.org/licenses/by-nc/4.0/. 
series of experiments, the investigators identified BMAL1 as the likely target of PPP4. As revealed by transient cotransfection assays, PPP4 directly interacts with the BMAL1-CLOCK heterodimer and diminishes its transactivation potential. Importantly, PPP4 accumulates in a circadian fashion and reaches zenith values just before the occupancy of E-box elements by the BMAL1-CLOCK complex is maximal. Thereby, PPP4 is likely to participate in delaying the activation of BMAL1-CLOCK target genes.

How does PPP4 reduce the transcription activation by the BMAL1-CLOCK complex? The phosphorylation status of BMAL1 could affect either its metabolic stability or its transactivation potential. The latter scenario appears to be more likely because the RNAi-mediated depletion of the catalytic subunit (PPP4CA) or the regulatory subunit (PPP4R2) of PPP4 did not affect nuclear BMAL1 levels. As disclosed by chromatin immunoprecipitation (ChIP) assays, the binding of BMAL1 to its cognate DNA elements in chromatin was lower after PPP4CA and PPP4R2 ablation. This finding was confirmed and extended by an independent experiment with a NIH3T3 cell line expressing a BMAL1-YFP fusion protein and harboring tandem arrays of $D b p$, a well-established BMAL1-CLOCK target gene (Stratmann et al. 2012). In these cells, the binding of BMAL1-CLOCK to E-box elements within the $D b p$ promoter results in fluorescent spots over the $D b p$ array. The binding dynamics of BMAL1-CLOCK to its cognate DNA elements can thus be recorded in real time and in individual cells by conducting fluorescence recovery after photobleaching (FRAP) and/or fluorescence loss in photobleaching (FLIP) assays. After depletion of PPP4R2, fewer fluorescent spots were observed and, as revealed by FRAP, the dwell time of BMAL1-CLOCK on the Dbp promoters was prolonged. This is consistent with previous studies demonstrating that BMAL1-CLOCK belongs to the category of kamikaze transcription factors (Stratmann et al. 2012). The maximal transactivation potential of such transcriptional activators depends on ubiquitination, which in turn may rely on their phosphorylation status. During the transactivation process, kamikaze transcription factors become ubiquitinated and undergo proteasome-induced degradation (Thomas and Tyers 2000). The cartoon in Figure 1 displays a hypothetical mechanism through which PPP4 may modulate the transcription of BMAL1-CLOCK target genes.

The loss-of-function experiments with fruit flies presented by Klemz et al. (2021) suggest that the PPP4-dependent transactivation by BMAL1-CLOCK is widespread among metazoans. Thus, the RNAi-mediated depletion of the Drosophila PPP4 regulatory subunit (PPP4R2r) in pacemaker neurons shortened the period of locomotor activity. Conversely, and as expected, PPP4R2r overexpression lengthened it.

What is next? The phosphorylated $\mathrm{S} / \mathrm{T}$ residues of BMAL1 that are dephosphorylated by PPP4 still remain to be identified, and some enigmas regarding the impact of PPP4 on the proposed kamikaze mechanism must be resolved. For example, the knockdown of PPP4R2 reduced both the equilibrium binding constant $\left(\mathrm{K}_{\mathrm{B}}\right)$ and the off-

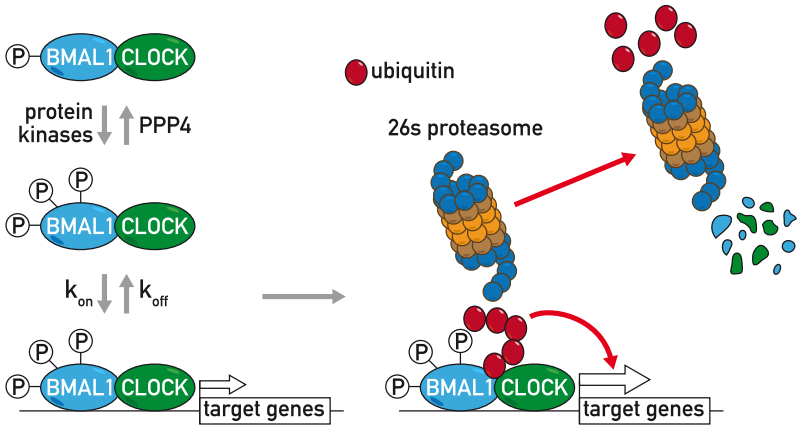

Figure 1. The activation of BMAL1-CLOCK target genes depends on the phosphorylation status of BMAL1, which in turn is determined by the balance of phosphorylation by protein kinases and dephosphorylation by PPP4. The chromatin-bound BMAL1-CLOCK heterodimer gets ubiquitinated (Sahar et al. 2010), which stimulates both its transactivation potential and its proteasome-mediated degradation. The PPP4-dependent phosphorylation status of BMAL1 can affect both the DNA-binding dynamics of BMAL1-CLOCK and its kamikaze-like target gene activation.

rate constant $\left(\mathrm{k}_{\mathrm{off}}\right)$ of BMAL1-chromatin binding. Since $\mathrm{K}_{\mathrm{B}}=\mathrm{k}_{\mathrm{on}} / \mathrm{k}_{\text {off, }}$ PPP4R2 depletion must lower the on-rate constant $\left(\mathrm{k}_{\mathrm{on}}\right)$ more dramatically than the off-rate constant $\left(\mathrm{k}_{\mathrm{off}}\right)$. The identification of the phosphorylated $\mathrm{S} / \mathrm{T}$ residues that are dephosphorylated by PPP4 will greatly help in clarifying how PPP4 tunes the kamikaze-like mechanism involved in the transactivation of BMAL1CLOCK target genes.

\section{Acknowledgments}

I thank Nicolas Roggli (Department of Molecular Biology, University of Geneva) for preparing Figure 1. Work in my laboratory was supported by the University of Geneva, the Swiss National Science Foundation (SNSF; grants 31-113565 and 31-128656/1), the European Research Council (ERC-2009-AdG TIMESIGNAL250117), and the Louis Jeantet Foundation, Geneva.

\section{References}

Dibner C, Schibler U, Albrecht U. 2010. The mammalian circadian timing system: organization and coordination of central and peripheral clocks. Annu Rev Physiol 72: 517-549. doi:10 .1146/annurev-physiol-021909-135821

Jang C, Lahens NF, Hogenesch JB, Sehgal A. 2015. Ribosome profiling reveals an important role for translational control in circadian gene expression. Genome Res 25: 1836-1847. doi:10 $.1101 /$ gr. 191296.115

Janich P, Arpat AB, Castelo-Szekely V, Lopes M, Gatfield D. 2015. Ribosome profiling reveals the rhythmic liver translatome and circadian clock regulation by upstream open reading frames. Genome Res 25: 1848-1859. doi:10.1101/gr.195404 .115

Klemz S, Wallach T, Korge S, Rosing M, Klemz R, Maier B, Fiorenza NC, Kaymak I, Fritzsche AK, Herzog ED, et al. 2021. Protein phosphatase 4 controls circadian clock dynamics by modulating CLOCK/BMAL1 activity. Genes Dev (this issue). doi:10.1101/gad.348622.121 
Schibler

Nakajima M, Imai K, Ito H, Nishiwaki T, Murayama Y, Iwasaki H, Oyama T, Kondo T. 2005. Reconstitution of circadian oscillation of cyanobacterial KaiC phosphorylation in vitro. Science 308: 414-415. doi:10.1126/science.1108451

Reischl S, Kramer A. 2011. Kinases and phosphatases in the mammalian circadian clock. FEBS Lett 585: 1393-1399. doi:10 $.1016 /$ j.febslet.2011.02.038

Sahar S, Zocchi L, Kinoshita C, Borrelli E, Sassone-Corsi P. 2010. Regulation of BMAL1 protein stability and circadian function by GSK3 $\beta$-mediated phosphorylation. PLoS One 5: e8561. doi:10.1371/journal.pone.0008561
Stratmann M, Suter DM, Molina N, Naef F, Schibler U. 2012. Circadian Dbp transcription relies on highly dynamic BMAL1CLOCK interaction with $\mathrm{E}$ boxes and requires the proteasome. Mol Cell 48: 277-287. doi:10.1016/j.molcel.2012.08.012

Thomas D, Tyers M. 2000. Transcriptional regulation: kamikaze activators. Curr Biol 10: R341-R343. doi:10.1016/S0960-9822 (00)00462-0

Toh KL, Jones CR, He Y, Eide EJ, Hinz WA, Virshup DM, Ptacek LJ, Fu YH. 2001. An hPer2 phosphorylation site mutation in familial advanced sleep phase syndrome. Science 291: 10401043. doi:10.1126/science.1057499 


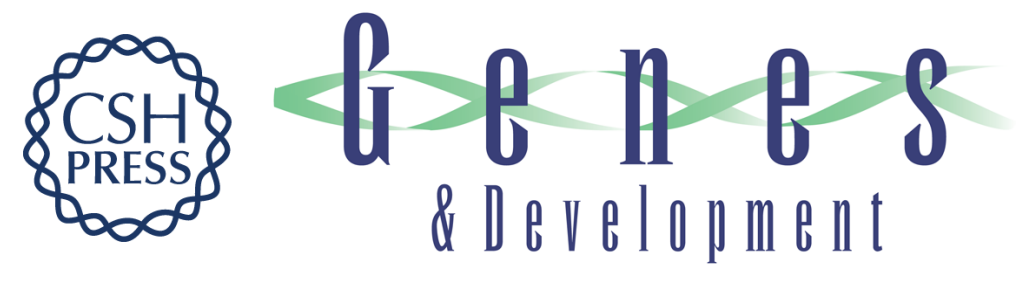

\section{BMAL1 dephosphorylation determines the pace of the circadian clock}

Ueli Schibler

Genes Dev. 2021, 35:

Access the most recent version at doi:10.1101/gad.348801.121

Related Content Protein phosphatase 4 controls circadian clock dynamics by modulating CLOCK/BMAL1 activity

Sabrina Klemz, Thomas Wallach, Sandra Korge, et al.

Genes Dev. August , 2021 35: 1161-1174

References This article cites 10 articles, 5 of which can be accessed free at:

http://genesdev.cshlp.org/content/35/15-16/1076.full.html\#ref-list-1

Articles cited in:

http://genesdev.cshlp.org/content/35/15-16/1076.full.html\#related-urls

Creative This article is distributed exclusively by Cold Spring Harbor Laboratory Press for the first Commons

License

six months after the full-issue publication date (see

http://genesdev.cshlp.org/site/misc/terms.xhtml). After six months, it is available under a Creative Commons License (Attribution-NonCommercial 4.0 International), as described at http://creativecommons.org/licenses/by-nc/4.0/.

Email Alerting Receive free email alerts when new articles cite this article - sign up in the box at the top Service right corner of the article or click here.

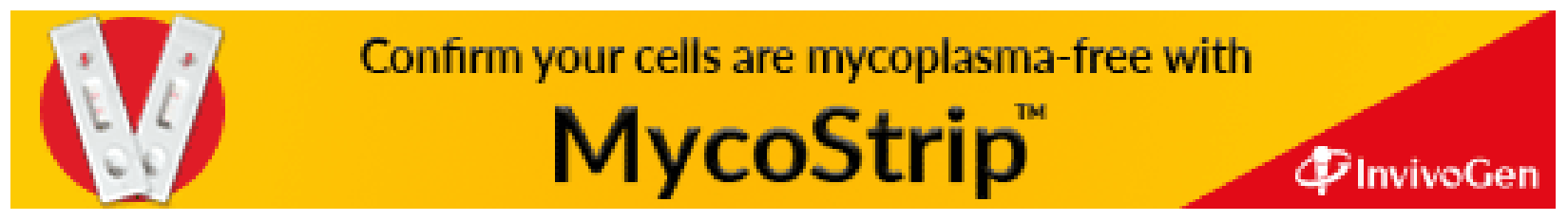

